\title{
RNA interference-mediated inhibition of ESCRT in mammalian cells
}

Katherine Bowers

Institute of Structural and Molecular Biology, Division of Biosciences, UCL, Gower

Street, London, WC1E 6BT

\begin{abstract}
Specific depletion of proteins from cultured cells using RNA interference (RNAi) has been a useful technique in assessing protein function for many years. RNAi allows the degradation of specific, targeted mRNA, allowing the effects of protein depletion on cellular processes to be examined. Here, I present a protocol for the depletion of proteins from cultured HeLa cells, and list specific reagents and considerations for targeting the endosomal sorting complexes required for transport (ESCRT).
\end{abstract}

\section{Keywords}

ESCRT, endosomes, siRNA, RNAi, protein depletion

\section{Running title}

siRNA depletion of ESCRTs

\section{Introduction}

The depletion of ESCRT proteins using RNA interference (RNAi) has been a widelyused technique over the past 17 years to investigate the function of ESCRT complexes in mammalian cells. Using RNAi, we have studied the role of ESCRT0, I, II and III, as well as associated proteins, in the trafficking of the epidermal growth factor receptor (EGFR), on overall endosomal morphology and in the fate of virally- 
ubiquitinated major histocompatibility complex class I (MHC class I) [1,2]. We have also used the same techniques to show that the sodium/ proton exchanger NHE8 plays a role in endosomal protein trafficking at multivesicular bodies [3].

RNAi can be used to silence genes with the transfection of short, interfering RNA duplexes (siRNA). The siRNAs are 21 base pair duplexes that are a perfect match to the target sequence $[4,5]$. The siRNAs allow a RNA-induced silencing complex (RISC) to bind to the target mRNA, leading a component of RISC, argonaute 2 (ago2), to unwind the siRNA [6]. The sense strand of the siRNA is degraded and activated RISC, with the antisense strand of the siRNA, is targeted to the complementary mRNA [7]. The mRNA of the gene of interest is degraded, leading to a depletion of protein levels $[8,7,9,10]$. RNAi therefore provides a simple way of depleting a protein of interest and studying the resultant phenotype. However, there are many factors that must be considered in setting up any RNAi experiment. Firstly, how effective will the siRNA depletion be? This can obviously be checked by real time quantitative PCR (to assess mRNA levels) and western blot (to study protein levels). To maximize the chance of effective silencing, a mix of four different siRNA duplexes is often used. Secondly, how specific will the process be, using the chosen siRNA duplexes or pool of duplexes? This second consideration is perhaps the most difficult to address. siRNA and micro RNAs (small, endogenous, regulatory RNAs) share the same RNAi effector, ago-2, and thus small RNAs loaded onto RISC may perform the functions of siRNA and micro RNA. Micro RNA suppresses partially complementary mRNA sequences and thus transfection of siRNA may result in many off-target effects via silencing unintended and partially complementary target sequences [11]. Steps can be taken to minimize and control for off-target effects. In 
addition, new techniques are being developed to minimize or eliminate off-target effects, as reviewed in [11].

Recent advances in gene-editing techniques (e.g. the clustered regulatory interspaced short palindromic repeats [CRISPR] and CRISPR-associated protein 9 [Cas9], CRISPR/Cas9 system) have led to the development of other ways to knockout or mutate ESCRT genes in mammalian tissue culture cells. CRISPR/Cas9 systems are being refined and improved and are already a very powerful tool for the analysis of gene function in mammalian systems. Indeed, CHMP2B-, TSG101-, VPS36- and ALIX-edited cell lines have been generated via CRIPSR/Cas9 [12-16]. A recent review of RNAi compared to CRISPR/Cas9 can be found here [17]. When choosing a method for ESCRT analysis, your own facilities, budget, time and ultimate goals will need to be considered carefully. RNAi has the advantage of being quick and simple, with many reagents commercially available. Gene editing by CRISPR/Cas9 is likely to be more complicated in standard laboratory cell lines (e.g. HeLa) that have chromosomal duplications, depletions or rearrangements, making RNAi a more straightforward choice. However, off-target effects are a major concern with RNAi and controls to validate any results must be performed. Here, I provide a detailed protocol for siRNA depletion of ESCRTs, as used in our studies [1,2]. This procedure is based on that used by Motley et al. [18]. It is our experience that siRNA-depletion of ESCRT proteins is most efficient using a " 2 hit" protocol. In summary, the cells are plated on day 0 , with transfections on days 1 and 3 and harvesting of the cells for further experiments on day 5 (but see Note 1). This protocol is for the transfection of HeLa M cells [19], and should give enough transfected cells to perform initial western 
blots and immunofluorescence experiments. The protocol can be scaled up or down as necessary for different experiments.

Before starting an siRNA protocol, it is extremely important to think about the controls required. Initial experiments should include controls to confirm that any effect of the transfection is due to the protein depletion and not a non-specific effect of the transfection procedure itself. This can be assessed by performing a mock transfection (i.e. performing the transfection procedure exactly as stated, but with RNase-free water in place of the siRNA oligonucleotide duplexes) or by purchasing specialised negative control oligonucleotides, designed to determine the baseline cellular response that occurs when transfecting non-specific siRNA oligonucleotides. You may also consider a positive control for the siRNA-transfection procedure and for this I recommend either using one of the oligonucleotides or pools of oligonucleotides listed here (Table 1), or purchasing a control set of oligonucleotides (e.g. targeting cylcophilin B or GAPD). Once initial experiments confirm a depletion of the protein of interest, validation of any associated phenotype by controlling for off-target effects is essential.

If possible, it is best to start with a pool of siRNA oligonucleotide duplexes, as this maximizes the chances that the protein of interest will be depleted [20]. In addition, the concentration of each individual duplex within the pool is lower (usually $1 / 4$ concentration) than would normally be used for individual duplexes. This lowers the risks of off-target effects, as these increase with the concentration of each duplex [21]. A table of pools and individual oligonucleotide duplexes for is provided for ESCRTs and related proteins (Table 1). 


\section{Materials}

\subsection{Cell growth medium for routine cell culture and selection of stable cell lines}

(see Note 2)

1. Routine culture medium for HeLa M cells: Roswell Park Memorial Institute medium (RPMI 1640) containing 2g/L sodium bicarbonate, supplemented with $2 \mathrm{mM}$ L-glutamine (see Note 3), 100 units $/ \mathrm{ml}$ penicillin, $0.1 \mathrm{mg} / \mathrm{ml}$ streptomycin (see Note 4), and 10\% (v/v) fetal bovine serum (FBS) (see Note 5).

Store at $4^{\circ} \mathrm{C}$.

Alternative routine culture medium for HeLa M cells: Dulbecco's Modified Eagle's Medium (DMEM) with $4.5 \mathrm{~g} / \mathrm{L}$ glucose, $0.11 \mathrm{~g} / \mathrm{L}$ sodium pyruvate and $3.7 \mathrm{~g} / \mathrm{L}$ sodium bicarbonate, supplemented with $2 \mathrm{mM}$ L-glutamine (see Note 3), 100 units/ml penicillin, $0.1 \mathrm{mg} / \mathrm{ml}$ streptomycin (see Note 4$)$, and 10\% (v/v) fetal bovine serum (FBS) (see Note 5).

Store at $4^{\circ} \mathrm{C}$.

2. Dulbecco's phosphate buffered saline (DPBS): $8 \mathrm{~g}$ sodium chloride, $0.2 \mathrm{~g}$ potassium phosphate, monobasic, $1.15 \mathrm{~g}$ sodium phosphate, dibasic, and $0.2 \mathrm{~g}$ potassium chloride. Made up to 1L with distilled water and sterilized.

Store at $4^{\circ} \mathrm{C}$. 
3. Hank's balanced salt solution with phenol red: $1 \mathrm{~g} / \mathrm{L}$ D-glucose, $400 \mathrm{mg} / \mathrm{L} \mathrm{KCl}, 60$ $\mathrm{mg} / \mathrm{L} \mathrm{KH}_{2} \mathrm{PO}_{4}, 8 \mathrm{~g} / \mathrm{L} \mathrm{NaCl}, 350 \mathrm{mg} / \mathrm{L} \mathrm{NaHCO}_{3}, 48 \mathrm{mg} / \mathrm{L} \mathrm{Na}_{2} \mathrm{HPO}_{4}$ (anhydrous), 10 $\mathrm{mg} / \mathrm{L}$ phenol red (sodium salt).

4. Trypsin solution: $0.5 \mathrm{~g} / \mathrm{L}$ porcine trypsin and $0.2 \mathrm{~g} / \mathrm{L}$ tetrasodium EDTA in Hank's balanced salt solution with phenol red.

Store at $4^{\circ} \mathrm{C}$.

5. Geneticin antibiotic (G418 sulfate): $50 \mathrm{mg} / \mathrm{ml}$ stock in distilled water, filter sterilize (see Note 6). This is used for the maintenance of stable cell lines, generated using vectors with neomycin resistance genes (e.g. pIRESneo2).

Store at $4^{\circ} \mathrm{C}$.

\section{2 siRNA transfection reagents and oligonucleotides}

1. Oligofectamine 2000 reagent and OptiMEM I reduced serum medium with Lglutamine and phenol red (see Note 7).

Store at $4^{\circ} \mathrm{C}$.

2. $20 \%$ FBS medium: RPMI or DMEM routine culture medium (section 2.1, point 1) with L-glutamine, but with an increase of the FBS to $20 \%$ and no antibiotics (see Note 8).

3. Solutions A and B for the transfection protocol, as shown in Table 2. Volumes for different sizes of culture dish are given. 
4. siRNA targeted against ESCRT components (Table 1). siRNA is supplied dry and should be made up at $50 \mu \mathrm{M}$ in RNase-free water.

Aliquot and store at $-20^{\circ} \mathrm{C}$. 
Table 1: siRNA oligonucleotide sequences targeting ESCRTs and other relevant genes (human sequences) that we have used. All siRNA duplexes were purchased from Dharmacon (Horizon Discovery). Where the oligonucleotides are available, the order numbers are given. For those that have been discontinued or were custom orders $(*)$, the target sequence is given.

\begin{tabular}{|c|c|c|c|c|c|c|c|}
\hline Gene & $\begin{array}{l}\text { Type of } \\
\text { oligonucleotide }\end{array}$ & Target sequence & $\begin{array}{l}5, \\
\text { modification }\end{array}$ & $\begin{array}{l}\text { ' } \\
\text { modification }\end{array}$ & $\begin{array}{l}\text { Dharmacon } \\
\text { catalogue } \\
\text { number }\end{array}$ & Accession number & Reference \\
\hline \multicolumn{8}{|l|}{ ESCRT 0} \\
\hline HRS (HGS) & $\begin{array}{l}\text { ON-TARGET } \\
\text { plus SMART } \\
\text { pool }\end{array}$ & & phosphate & UU & L-016835-00 & NM_004712 & {$[2]$} \\
\hline \multicolumn{8}{|l|}{ ESCRT I } \\
\hline TSG101 (VPS23) & $\begin{array}{l}\text { Custom } \\
\text { siGENOME } \\
\text { SMART pool }\end{array}$ & CCTCCAGTCTTCTCTCGTC & $\begin{array}{l}\text { none } \\
\text { phosphate }\end{array}$ & $\begin{array}{l}\text { dTdT } \\
\text { UU }\end{array}$ & $\begin{array}{l}\text { N/A } \\
\text { M-003549-01 }\end{array}$ & NM_006292 & $\begin{array}{l}{[5,1,22]} \\
{[2]}\end{array}$ \\
\hline \multicolumn{8}{|l|}{ ESCRT II } \\
\hline $\begin{array}{l}\text { VPS22 (EAP30, } \\
\text { SNF8) }\end{array}$ & $\begin{array}{l}\text { Custom SMART } \\
\text { pool }\end{array}$ & Sequences unknown & phosphate & UU & * & NM_001317192 & {$[1]$} \\
\hline VPS25 (EAP20) & $\begin{array}{l}\text { Custom SMART } \\
\text { pool } \\
\text { Custom SMART } \\
\text { pool \#1 } \\
\text { Custom SMART } \\
\text { pool \#2 } \\
\text { Custom SMART } \\
\text { pool \#3 } \\
\text { Custom SMART } \\
\text { pool \#4 }\end{array}$ & $\begin{array}{l}\text { Pool of sequences 1-4 listed below } \\
\text { CAGAACAACTCCGTCTTTA } \\
\text { GCACAAGGCCGAGATCATC } \\
\text { GGGAAACTCATCTATCAGT } \\
\text { GTCGATCCAGATTGTATTA }\end{array}$ & $\begin{array}{l}\text { phosphate } \\
\text { phosphate } \\
\text { phosphate } \\
\text { phosphate } \\
\text { phosphate }\end{array}$ & $\begin{array}{l}\text { UU } \\
\text { UU } \\
\text { UU } \\
\text { UU } \\
\text { UU }\end{array}$ & $*$ & NM_032353 & $\begin{array}{l}{[1]} \\
{[1]} \\
{[1]} \\
{[1]} \\
{[1]}\end{array}$ \\
\hline VPS36 (EAP45) & $\begin{array}{l}\text { Custom SMART } \\
\text { pool }\end{array}$ & Sequences unknown & phosphate & UU & * & NM_001282168 & {$[1]$} \\
\hline
\end{tabular}




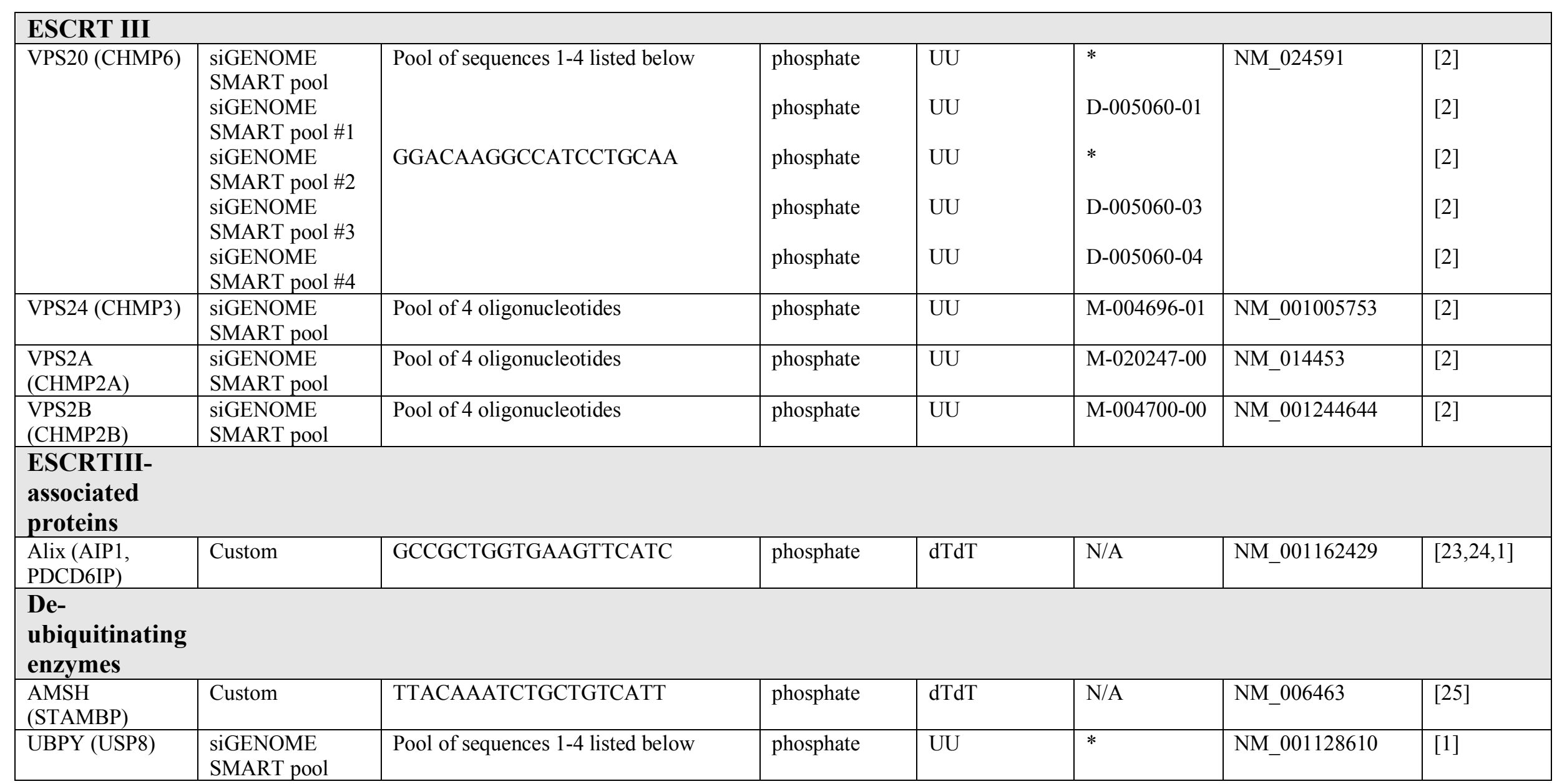




\begin{tabular}{|l|l|l|l|l|l|l|}
\hline $\begin{array}{l}\text { Dish size } \\
\text { (area) }\end{array}$ & \multicolumn{2}{|l|}{$\begin{array}{l}\text { Solution } \\
\text { A }\end{array}$} & $\begin{array}{l}\text { Solution } \\
\text { B }\end{array}$ & $\begin{array}{l}\text { Additions } \\
\text { after 20 } \\
\text { min }\end{array}$ & $\begin{array}{l}\text { Additions } \\
\text { after 4 h }\end{array}$ \\
\hline & $\begin{array}{l}\text { OptiMEM } \\
(\mu \mathrm{l})\end{array}$ & $\begin{array}{l}\text { siRNA, } \\
50 \mu \mathrm{M} \\
\text { stock } \\
(\mu \mathrm{l})\end{array}$ & $\begin{array}{l}\text { OptiMEM } \\
\text { I }(\mu \mathrm{l})\end{array}$ & $\begin{array}{l}\text { Oligo- } \\
\text { fectamine } \\
(\mu \mathrm{l})\end{array}$ & $\begin{array}{l}\text { OptiMEM } \\
\text { I } \\
(\mathrm{ml})\end{array}$ & $\begin{array}{l}\text { 20\% FBS } \\
\text { medium } \\
(\mathrm{ml})\end{array}$ \\
\hline $\begin{array}{l}\text { One well } \\
\text { of 6-well } \\
\text { plate } \\
\left(8.87 \mathrm{~cm}^{2}\right)\end{array}$ & 166 & 4 & 20 & 10 & 0.8 & 1 \\
\hline $\begin{array}{l}6 \mathrm{~cm}(21 \\
\left.\mathrm{cm}^{2}\right)\end{array}$ & 332 & 8 & 40 & 20 & 1.6 & 2 \\
\hline $\begin{array}{l}10 \mathrm{~cm}(58 \\
\left.\mathrm{cm}^{2}\right)\end{array}$ & 830 & 20 & 100 & 50 & 4.0 & 5 \\
\hline
\end{tabular}

Table 2. Solutions for siRNA transfection of HeLa M cells. * This concentration of siRNA gives a final concentration of an oligonucleotide pool of $100 \mathrm{nM}(25 \mathrm{nM}$ each oligonucleotide duplex), after all additions (see Note 9).

\subsection{Solutions for fixation and cell lysis}

1. PBS: $137 \mathrm{mM} \mathrm{NaCl}, 2.7 \mathrm{mM} \mathrm{KCl}, 10 \mathrm{mM} \mathrm{Na}_{2} \mathrm{HPO}_{4}, 2 \mathrm{mM} \mathrm{KH}_{2} \mathrm{PO}_{4}$, in distilled water (see Note 10).

2. Fixative: $3 \%(\mathrm{w} / \mathrm{v})$ paraformaldehyde in PBS (see Note 11).

3. Cell lysis solution: $0.5 \%$ (v/v) Nonidet P-40, $150 \mathrm{mM} \mathrm{NaCl}, 2 \mathrm{mM}$ EDTA, $20 \mathrm{mM}$ Tris, $\mathrm{pH}$ 8. This solution is ideally made fresh and chilled on ice before use. Add $1 \mathrm{X}$ protease inhibitors (see Note 12) prior to use. 


\section{Method}

Work in a tissue culture hood, using sterile equipment and good sterile technique throughout.

\subsection{Routine cell culture}

1. Trypsinize cells from a $10 \mathrm{~cm}$ tissue culture dish as follows: Warm all media to $37^{\circ} \mathrm{C}$ (see Note 13 ). Remove medium from cell culture plate, wash cells gently with 5 $\mathrm{ml}$ DPBS, remove DPBS and add $2 \mathrm{ml}$ trypsin solution. Incubate at $37^{\circ} \mathrm{C}$ until the cells are rounded up and begin to float off the dish (approximately $5 \mathrm{~min}$ ). Add $8 \mathrm{ml}$ routine culture medium and gently pipette up and down to mix and break up clumps.

2. To new $10 \mathrm{~cm}$ dishes, add 1-2 $\mathrm{ml}$ cell suspension and make up to $10 \mathrm{ml}$ with culture medium (see Note 14). If the cell line is a stable, G418-resistant line, add G418 as appropriate (see Note 6).

\subsection{Day 0: Plating the cells prior to transfection}

1. Trypsinize cells (section 3.1, point 1 ).

2. Count the cells using a haemocytometer following the manufacturer's instructions. Plate $1.5 \times 10^{5}$ cells per well of a 6 well plate, in a total volume of $2 \mathrm{ml}$ routine culture medium (see Note 15). Set up one well per transfection, and incubate overnight in a standard tissue culture incubator at $37^{\circ} \mathrm{C}$ with $5 \% \mathrm{CO}_{2}$. Transfection volumes for other sized dishes are given in Table 1 for reference. 


\subsection{Day 1: siRNA transfection 1}

1. For the first transfection, make up enough solution B (Table 2) for all the transfections (see Note 16), and incubate for $5 \mathrm{~min}$ at room temperature.

2. Make up solution A in individual sterile tubes. Use tubes that can take a total volume of at least $1 \mathrm{ml}$.

3. Add solution B to the solution A tubes and mix by gentle pipetting. Incubate at room temperature for $20 \mathrm{~min}$.

4. Towards the end of the 20 min incubation in step 3, wash the cells once with $1.5 \mathrm{ml}$ pre-warmed DPBS to remove traces of FBS (see Note 17).

5. Add $0.8 \mathrm{ml}$ OptiMEM I to the mixed solutions A and B from step 3, and mix by gentle pipetting.

6. Remove the DPBS from the cells and add the whole mix from step 5. Incubate for $4 \mathrm{~h}$ at $37^{\circ} \mathrm{C}$ in a $5 \% \mathrm{CO}_{2}$ incubator.

7. Add $1 \mathrm{ml} \mathrm{20 \%} \mathrm{FBS} \mathrm{medium} \mathrm{and} \mathrm{rock} \mathrm{the} \mathrm{plate} \mathrm{very} \mathrm{gently} \mathrm{to} \mathrm{mix.} \mathrm{Incubate}$ overnight at $37^{\circ} \mathrm{C}, 5 \% \mathrm{CO}_{2}$. 


\subsection{Days 2 and 3: Split cells and complete siRNA transfection 2}

1. In the morning, replace the transfection medium on the cells with routine culture medium (containing antibiotics, as necessary).

2. In the afternoon of day 2 (4-5 h after step 1$)$, trypsinize the cells as described in section 3.1 , point 1 , using $1.5 \mathrm{ml}$ DPBS, $0.5 \mathrm{ml}$ trypsin solution and $2.5 \mathrm{ml}$ routine culture medium. Transfer all cells into $6 \mathrm{~cm}$ culture dishes and add a further $2 \mathrm{ml}$ routine culture medium. Rock the plates very gently to mix and then incubate overnight at $37^{\circ} \mathrm{C}, 5 \% \mathrm{CO}_{2}$.

3. On day 3 , repeat the transfection procedure as in section 3.3, using the volumes in Table 1 for $6 \mathrm{~cm}$ dishes.

\subsection{Day 4: Plate out cells}

1. Replace the transfection medium on the cells with routine culture medium (containing antibiotics, as necessary).

2. After $4-5 \mathrm{~h}$, wash the cells once with $2.5 \mathrm{ml}$ pre-warmed DPBS, trypsinize as in section 3.1, point 1 , using $1 \mathrm{ml}$ trypsin solution and resuspend with $1 \mathrm{ml}$ routine growth medium (to give a total of $2 \mathrm{ml}$ cell suspension). Add $100 \mu 1$ cell suspension per well to a 4-well (or 24-well) plate (growth area $1.82 \mathrm{~cm}^{2}$ ) containing a sterile glass coverslip for immuno-staining (see Note 18). Add $1 \mathrm{ml}$ routine culture medium 
per well. The remaining cell suspension can be added to a $6 \mathrm{~cm}$ culture dish and the volume made up to $5 \mathrm{ml}$ with routine culture medium.

\subsection{Day 5: Test efficiency of knockdown (see Note 19)}

1. Fix cells on coverslips as follows (see Note 20$)$ : wash 3 times with PBS ( $1 \mathrm{ml}$ per wash), incubate in fixative for $15 \mathrm{~min}$ at room temperature, wash a further 2 times with PBS. Continue with a standard procedure for immunostaining adherent, fixed cells to localise the protein(s) of interest $[1,26]$.

2. Wash cells in $6 \mathrm{~cm}$ dishes 3 times in $5 \mathrm{ml}$ cold PBS, on ice. Remove PBS and add $2.5 \mathrm{ml}$ cold PBS. Using a plastic cell scraper, scrape the cells into the PBS and transfer to a $15 \mathrm{ml}$ tube. Add a further $2.5 \mathrm{ml}$ PBS and scrape the cells again, added this to the same tube ( $5 \mathrm{ml}$ cell suspension). Spin down cells gently at $4^{\circ} \mathrm{C}, 5 \mathrm{~min}$, $1000 \times g$. Remove PBS and resuspend the cells in cold cell lysis solution. Incubate $15 \mathrm{~min}$ on ice. Remove cell debris and nuclei by a further spin at $16000 \mathrm{x} g$ for 20 min at $4^{\circ} \mathrm{C}$, and remove the post-nuclear supernatant (lysate) to a fresh tube. Discard the pellet. Carry out a protein assay on the lysate (see Note 21), and load equal amounts of protein per lane for SDS polyacrylamide gel electrophoresis (PAGE) and western blot, using standard procedures [1,26], see Fig. 1 .

FIGURE 1 HERE

\subsection{Validation (see Note 22)}


1. Repeat the siRNA transfections using individual oligonucleotides (if previously a pool was used). See Note 23 and Fig. 1.

2. Titrate the siRNA oligonucleotides to the lowest possible concentration that still produces the phenotype, to minimize off-target effects (see Note 24 and Fig. 1).

3. Rescue the phenotype seen using an siRNA-resistant version of the cDNA of interest (see Note 25). To do this, choose one siRNA oligonucleotide (usually the most efficient for knockdown). Generate a mutant cDNA by site-directed mutagenesis with silent mutations (i.e. mutations that do not change the amino acid sequence in the protein) along the length of the oligonucleotide binding site (see Note 26). This mutated version of the cDNA can then be transfected into the cells prior to siRNA transfection (we would normally create a stable cell line expressing the mutant protein). Repeat siRNA transfections in the cell line expressing the siRNA-resistant mRNA and determine whether the phenotype seen is corrected or "rescued" by the exogenous protein.

\section{Notes}

1. For TSG101 (VPS23, part of ESCRTI), transfections were carried out on days 2 and 3 to avoid the extensive cell death seen after the longer transfection protocol. For VPS2A (CHMP2A, part of ESCRTIII), only one transfection was carried out, on day 1, again to avoid extensive cell death. 
2. Media for tissue culture, including DMEM, RPMI 1640, trypsin solution, DPBS, G418 and other listed supplements can be purchased from cell culture suppliers.

3. $200 \mathrm{mM} \mathrm{L}$-glutamine is purchased as a stock in $50 \mathrm{ml}$ quantities. Store at $-20^{\circ} \mathrm{C}$ until required and then thaw at $37^{\circ} \mathrm{C}$ in a water bath (some agitation is usually required to get all the glutamine into solution). $5 \mathrm{ml}$ aliquots (sufficient for a $500 \mathrm{ml}$ bottle of medium) are made under sterile conditions into sterile tubes for storage at $20^{\circ} \mathrm{C}$. Thaw at $37^{\circ} \mathrm{C}$ before use.

4. A stock of 10000 units penicillin and $10 \mathrm{mg}$ streptomycin per $\mathrm{ml}$ is purchased in $50 \mathrm{ml}$ quantities. Store at $-20^{\circ} \mathrm{C}$ and thaw at $37^{\circ} \mathrm{C}$ in a water bath. As with Lglutamine (see Note 3), make $5 \mathrm{ml}$ aliquots and store at $-20^{\circ} \mathrm{C}$ until required.

5. FBS is purchased in $500 \mathrm{ml}$ quantities and stored at $-20^{\circ} \mathrm{C}$. Thaw (in a $37^{\circ} \mathrm{C}$ waterbath), and filter the FBS through a $0.2 \mu \mathrm{m}$ syringe filter (several are usually required for a $500 \mathrm{ml}$ bottle of $\mathrm{FBS}$, as they clog easily). Make $50 \mathrm{ml}$ aliquots in sterile tubes. The aliquots are frozen, and thawed as required. $50 \mathrm{ml}$ is sufficient for one $500 \mathrm{ml}$ bottle of complete medium with $10 \%$ FBS.

6. The concentration of G418 antibiotic is titrated for each batch and each cell line, but usually ranges from $0.2-0.5 \mathrm{mg} / \mathrm{ml}$ in routine culture medium, to select and culture stable cell lines. 
7. Oligofectamine 2000 and OptiMEM I reduced serum medium with L-glutamine and phenol red are proprietary formulations, supplied by Thermo Fisher Scientific. I have not tested other, similar reagents.

8. For $100 \mathrm{ml}$ of $20 \%$ FBS medium, add $20 \mathrm{ml} \mathrm{FBS}$ and $1 \mathrm{ml} \mathrm{L}$-glutamine stock to 79 ml DMEM or RPMI culture medium.

9. Use sterile filter tips on pipettes for the siRNA transfection. The siRNA concentration given is a good starting point, but pools and individual duplexes should be titrated so that the lowest concentration is used to achieve depletion of the protein. Volumes are given for different sized wells or dishes. The dish/ well chosen will depend on how many cells are required for further analysis.

10. Make a 10X stock of PBS, sterilize, and dilute to $1 \mathrm{X}$ prior to use.

11. Make $6 \%(\mathrm{w} / \mathrm{v})$ paraformaldehyde stock in PBS. This solution should be made in a fume hood, and requires heating to about $80^{\circ} \mathrm{C}$ to dissolve. Once cooled, add $10 \mu \mathrm{L}$ $\mathrm{MgCl}_{2}$ and $10 \mu \mathrm{LaCl}_{2}$. Store in aliquots at $-20^{\circ} \mathrm{C}$. Thaw and dilute $1: 1$ with PBS just prior to use.

12. Protease inhibitor tablets (cOmplete ${ }^{\mathrm{TM}}$, Mini, EDTA-free Protease Inhibitor Cocktail) are a proprietary formulation from Roche. 
13. Pre-warming the media speeds up the trypsinization process and avoids possible cold stress to the cells.

14. HeLa M cells should be maintained by splitting 1:5 to 1:10 twice per week: Use a plate that is just confluent (i.e. the cells are just touching each other) and trypsinize and plate onto new plates as described. Maintain some cells for future use and plate some for siRNA transfection, as required.

15. If necessary, the cells can be plated on Day 1 (rather than Day 0). In this case, add $5 \times 10^{5}$ cells per well of a 6 well plate and leave for at least $3 \mathrm{~h}$ to adhere to the plastic before transfection. For other plate or dish sizes, scale the number of cells plated depending on the surface area.

16. Make up a little more Solution B than required to ensure you have enough.

17. Traces of FBS will decrease the transfection efficiency.

18. To prepare sterile, circular glass coverslips ( $13 \mathrm{~mm}$ diameter): wash in $70 \%$ ethanol and dry with tissue. Ensure coverslips are completely dry. Place in a glass petri dish in single layers, divided by filter paper. Bake at $180^{\circ} \mathrm{C}$ in an oven for at least $2 \mathrm{~h}$ and cool before use.

19. The efficiency of the siRNA knockdown must be assessed before further experiments can be conducted. This is perhaps best done by a combination of SDSPAGE/ western blotting and immunofluorescent staining, assuming an antibody 
specific to the protein of interest is available. In this case, a western blot will give an overall idea of the percentage protein depletion, compared to mock or controltransfected cells and with a suitable loading control (e.g. anti-calreticulin). Immunofluorecence will allow you to assess the extent of knockdown and in which cells specifically the protein is depleted: For example, a 90\% depletion of a particular protein may be the result of $90 \%$ depletion levels in all cells, or may be the result of $90 \%$ of the cells having no detectable protein but $10 \%$ of the cells having near wild type levels. The latter is more common, in my experience. Most of the siRNA oligonucleotides or oligonucleotide pools in Table 1 should give $90 \%$ or greater depletion efficiency, but this should be assessed for each transfection. If an antibody to the protein of interest is not available, then siRNA efficiency may be studied using real time quantitative polymerase chain reaction to assess the depletion of mRNA. Transfection in 6 well plates moving to $6 \mathrm{~cm}$ dishes should give adequate numbers of cells for an initial investigation of depletion of the protein of interest. The cells can also be used for a variety of other assays, including real time quantitative PCR (RTPCR, to assess the depletion of mRNA levels), fluorescence activated cell sorting (FACS) analysis, biochemical assays (including ${ }^{125}$ I-EGF uptake assays) and electron microscopy [1,2], although the procedure may need scaling up to give satisfactory cell numbers on day 5. Also see Note 1.

20. Once the siRNA transfections are complete and the cells are removed from the tissue culture room for fixation and lysate preparation, there is no need to maintain sterile technique. 
21. Many protein assay methods are available. We use a bicinchoninic acid-based method. Whichever method is chosen, it is essential to generate a standard curve and to ensure that the samples measure are within the linear range of the assay.

22. Following siRNA-depletion of a protein of interest, it is essential that any phenotype observed is validated to ensure it is a result of depletion of that protein (directly or indirectly) and not a consequence of non-specific effects of the oligonucleotide duplexes used. I recommend reading an editorial in Nature Cell Biology regarding validation of siRNA [27].

23. The first step in validation is to determine which of the four oligonucleotides used (if using a pool) give rise to efficient depletion, and which also gives rise to the phenotype of interest. One would expect three or four of the siRNA duplexes used to give rise to efficient mRNA and protein depletion, and it goes some way to validating the procedure if all siRNA that deplete the protein also show the observed phenotype.

24. It is important to titrate the concentration of siRNA to the lowest possible able to achieve effective depletion, to minimize off-target effects [21]. An example of VPS20 (CHMP6) depletion using both a pool and individual duplexes at various concentrations is shown in Fig. 1. As can be seen, efficient depletion is seen even with $5 \mathrm{nM}$ of the pool (i.e. $1.25 \mathrm{nM}$ each oligonucleotide duplex). Of the individual oligonucleotide duplexes, number 2 is not particularly effective but numbers 1,3 and 4 give effective protein knockdown. 
25. The rescue experiment is the best validation of an observed effect of protein depletion. However, it may not be possible for a variety of reasons. For example, a transfected cell line (even a stable cell line) will often express much higher levels of the protein of interest than is expressed endogenously and thus rescue may be partial or possibly not apparent. Overexpression of the construct of interest may in itself may also cause a phenotype (this has been documented for ESCRTs, e.g. expression of N-terminally tagged TSG101, ALIX (AIP1), VPS2A (CHMP2A), VPS32A (CHMP4A), VPS32B (CHMP4B), VPS32C (CHMP4C), CHMP1A, CHMP1B and CHMP5 disrupts HIV-1 production [28]). Ultimately, the controls should validate the effects of protein depletions seen, by the best methods available to you. This may, of course, include complementary techniques (such as CRISPR-Cas 9 gene editing) to mutate the protein of interest and validate the data.

26. Any translational effects of silent mutations can be avoided by using an siRNA that targets the 3'UTR.

\section{Figure legend}

Fig. 1. RNAi depletion of VPS20 (CHMP6) in HeLa M cells. The doubletransfection RNAi protocol described was used, with either a pool of siRNAs targeting VPS20 at varying concentrations or each of the individual siRNAs at $25 \mathrm{nM}$ (see Table 1). Mock-transfected cells are included for comparison. $33 \mu \mathrm{g}$ total protein lysate was loaded per lane on SDS-PAGE, the gel blotted to nitrocellulose and the resulting western blot cut between the 33 and $48 \mathrm{kDa}$ markers. The upper half was 
probed with anti-calreticulin as a loading control and the lower half with anti-VPS20 [2].

\section{References}

1. Bowers K, Piper SC, Edeling MA, Gray SR, Owen DJ, Lehner PJ, Luzio JP (2006) Degradation of endocytosed epidermal growth factor and virally ubiquitinated major histocompatibility complex class I is independent of mammalian ESCRTII. J Biol Chem 281 (8):5094-5105. doi:10.1074/jbc.M508632200

2. Parkinson MD, Piper SC, Bright NA, Evans JL, Boname JM, Bowers K, Lehner PJ, Luzio JP (2015) A non-canonical ESCRT pathway, including histidine domain phosphotyrosine phosphatase (HD-PTP), is used for down-regulation of virally ubiquitinated MHC class I. Biochem J 471 (1):79-88. doi:10.1042/BJ20150336 3. Lawrence SP, Bright NA, Luzio JP, Bowers K (2010) The sodium/proton exchanger NHE8 regulates late endosomal morphology and function. Mol Biol Cell 21 (20):3540-3551. doi:10.1091/mbc.E09-12-1053

4. Elbashir SM, Harborth J, Lendeckel W, Yalcin A, Weber K, Tuschl T (2001) Duplexes of 21-nucleotide RNAs mediate RNA interference in cultured mammalian cells. Nature 411 (6836):494-498. doi:10.1038/35078107

5. Garrus JE, von Schwedler UK, Pornillos OW, Morham SG, Zavitz KH, Wang HE, Wettstein DA, Stray KM, Cote M, Rich RL, Myszka DG, Sundquist WI (2001) Tsg101 and the vacuolar protein sorting pathway are essential for HIV-1 budding. Cell 107 (1):55-65 
6. Rand TA, Ginalski K, Grishin NV, Wang X (2004) Biochemical identification of Argonaute 2 as the sole protein required for RNA-induced silencing complex activity. Proc Natl Acad Sci U S A 101 (40):14385-14389. doi:10.1073/pnas.0405913101 7. Matranga C, Tomari Y, Shin C, Bartel DP, Zamore PD (2005) Passenger-strand cleavage facilitates assembly of siRNA into Ago2-containing RNAi enzyme complexes. Cell 123 (4):607-620. doi:10.1016/j.cell.2005.08.044

8. Ameres SL, Martinez J, Schroeder R (2007) Molecular basis for target RNA recognition and cleavage by human RISC. Cell 130 (1):101-112. doi:10.1016/j.cell.2007.04.037

9. Rand TA, Petersen S, Du F, Wang X (2005) Argonaute2 cleaves the anti-guide strand of siRNA during RISC activation. Cell 123 (4):621-629. doi:10.1016/j.cell.2005.10.020

10. Whitehead KA, Langer R, Anderson DG (2009) Knocking down barriers: advances in siRNA delivery. Nat Rev Drug Discov 8 (2):129-138. doi: $10.1038 / \operatorname{nrd} 2742$

11. Seok H, Lee H, Jang ES, Chi SW (2017) Evaluation and control of miRNA-like off-target repression for RNA interference. Cell Mol Life Sci. doi:10.1007/s00018017-2656-0

12. Meng B, Ip NC, Prestwood LJ, Abbink TE, Lever AM (2015) Evidence that the endosomal sorting complex required for transport-II (ESCRT-II) is required for efficient human immunodeficiency virus-1 (HIV-1) production. Retrovirology 12:72. doi:10.1186/s12977-015-0197-X

13. Sanyal S, Ashour J, Maruyama T, Altenburg AF, Cragnolini JJ, Bilate A, Avalos AM, Kundrat L, Garcia-Sastre A, Ploegh HL (2013) Type I interferon imposes a 
TSG101/ISG15 checkpoint at the Golgi for glycoprotein trafficking during influenza virus infection. Cell Host Microbe 14 (5):510-521. doi:10.1016/j.chom.2013.10.011 14. Zhang Y, Schmid B, Nielsen TT, Nielsen JE, Clausen C, Hyttel P, Holst B, Freude KK (2016) Generation of a human induced pluripotent stem cell line via CRISPR-Cas9 mediated integration of a site-specific heterozygous mutation in CHMP2B. Stem Cell Res 17 (1):148-150. doi:10.1016/j.scr.2016.06.004 15. Zhang Y, Schmid B, Nikolaisen NK, Rasmussen MA, Aldana BI, Agger M, Calloe K, Stummann TC, Larsen HM, Nielsen TT, Huang J, Xu F, Liu X, Bolund L, Meyer M, Bak LK, Waagepetersen HS, Luo Y, Nielsen JE, Consortium FR, Holst B, Clausen C, Hyttel P, Freude KK (2017) Patient iPSC-Derived Neurons for Disease Modeling of Frontotemporal Dementia with Mutation in CHMP2B. Stem Cell Reports 8 (3):648-658. doi:10.1016/j.stemcr.2017.01.012

16. Fedele AO, Isenmann S, Kamei M, Snel MF, Trim PJ, Proud CG, Hopwood JJ (2018) Lysosomal N-acetyltransferase interacts with ALIX and is detected in extracellular vesicles. Biochim Biophys Acta. doi:10.1016/j.bbamcr.2018.07.001 17. Unniyampurath U, Pilankatta R, Krishnan MN (2016) RNA Interference in the Age of CRISPR: Will CRISPR Interfere with RNAi? Int J Mol Sci 17 (3):291. doi:10.3390/ijms17030291

18. Motley A, Bright NA, Seaman MN, Robinson MS (2003) Clathrin-mediated endocytosis in AP-2-depleted cells. J Cell Biol 162 (5):909-918. doi:10.1083/jcb.200305145

19. Kusari J, Sen GC (1986) Regulation of synthesis and turnover of an interferoninducible mRNA. Mol Cell Biol 6 (6):2062-2067 
20. Parsons BD, Schindler A, Evans DH, Foley E (2009) A direct phenotypic comparison of siRNA pools and multiple individual duplexes in a functional assay. PLoS One 4 (12):e8471. doi:10.1371/journal.pone.0008471

21. Semizarov D, Frost L, Sarthy A, Kroeger P, Halbert DN, Fesik SW (2003) Specificity of short interfering RNA determined through gene expression signatures. Proc Natl Acad Sci U S A 100 (11):6347-6352. doi:10.1073/pnas.1131959100 22. Hewitt EW, Duncan L, Mufti D, Baker J, Stevenson PG, Lehner PJ (2002) Ubiquitylation of MHC class I by the K3 viral protein signals internalization and TSG101-dependent degradation. EMBO J 21 (10):2418-2429. doi:10.1093/emboj/21.10.2418

23. Cabezas A, Bache KG, Brech A, Stenmark H (2005) Alix regulates cortical actin and the spatial distribution of endosomes. J Cell Sci 118 (Pt 12):2625-2635. doi: $10.1242 /$ jcs. 02382

24. Matsuo H, Chevallier J, Mayran N, Le Blanc I, Ferguson C, Faure J, Blanc NS, Matile S, Dubochet J, Sadoul R, Parton RG, Vilbois F, Gruenberg J (2004) Role of LBPA and Alix in multivesicular liposome formation and endosome organization. Science 303 (5657):531-534. doi:10.1126/science.1092425

25. McCullough J, Clague MJ, Urbe S (2004) AMSH is an endosome-associated ubiquitin isopeptidase. J Cell Biol 166 (4):487-492. doi:10.1083/jcb.200401141 26. Harlow E, Lane D (1999) Using Antibodies: A Laboratory Manual. Cold Spring Harbor Laboratory Press, Cold Spring Harbor, New York 27. Whither RNAi? (2003). Nat Cell Biol 5 (6):489-490. doi:10.1038/ncb0603-490 28. Martin-Serrano J, Yarovoy A, Perez-Caballero D, Bieniasz PD (2003) Divergent retroviral late-budding domains recruit vacuolar protein sorting factors by using 
alternative adaptor proteins. Proc Natl Acad Sci U S A 100 (21):12414-12419. doi:10.1073/pnas.2133846100 


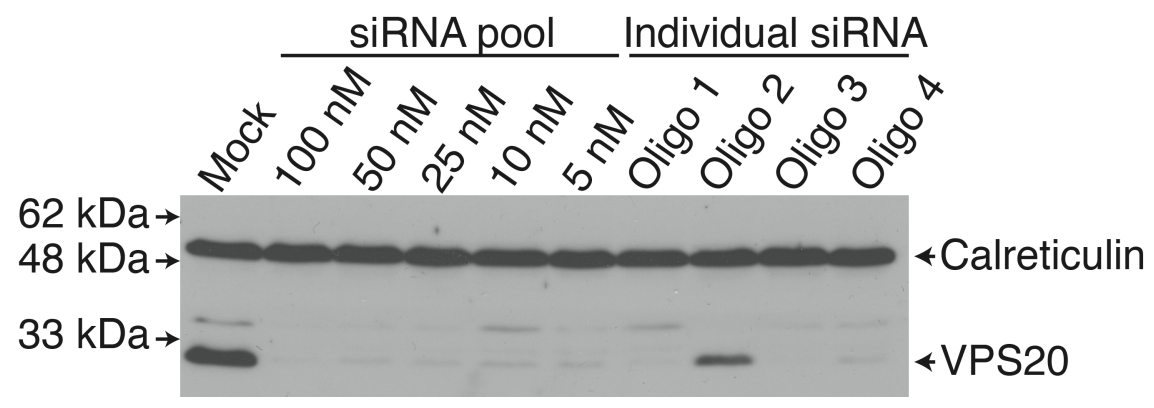

